\title{
Sesmum indicum Oil as a Potential Inhibitor for the Corrosion of Copper in Acidic Environment
}

\author{
ANURAG SHARMA ${ }^{1 *}$, ANIL KUMAR VARSHNEY² and SARITA VARSHNEY² \\ 'Swami Keshvanand Institute of Technology,Management \& Gramothan, Jaipur, Rajasthan, India. \\ ${ }^{2}$ Department of Chemistry, University of Rajasthan, Jaipur, Rajasthan, India: \\ ${ }^{*}$ Corresponding author E-mail: anuragsharma20oct@yahoo.co.in
}

http://dx.doi.org/10.13005/ojc/320551

(Received: September 10, 2016; Accepted: October 19, 2016)

\begin{abstract}
The inhibitory action of sesmum indicum oil on the surface of copper metal in $0.5 \mathrm{~N} \mathrm{HCl}$ using gravimetric and galvanostatic polarization methods has been investigated. The rates of corrosion of copper metal with hydrochloric acid containing sesmum indicum oil were obtained as a function of the oil amount. The inhibitor efficiency was found to depend on the concentration of the sesmum indicum oil. Adsorption of sesmum indicum oil on copper metal was followed the Langmuir adsorption isotherm. The phenomenon of physical adsorption has been proposed on the basis of evaluated thermodynamic parameters.
\end{abstract}

Keywords: Corrosion, Gravimetric technique, Sesmum indicum oil, Galvanostatic polarization.

\section{INTRODUCTION}

Control of metal's corrosion is a sensitive part of scientific, commercially, and atmospherically point of view. The work on latest and eco friendly corrosion inhibitors has become a necessary to protect different important metals from corrosion. The appreciable works have been made to search suitable organic compounds which to be used as corrosion inhibitors in different acidic solutions, to retard the extreme attack on the metal. On account of the well known negative consequence of most artificial corrosion inhibitors and the need to work on economical, harmless and eco friendly benign processes, the efforts have been done by many investigators to attention, on the work of eco friendly corrosion inhibitor ${ }^{1-8}$. Some of the natural oils are also found to be the good corrosion inhibitor like natural Artemisia oil $^{9}$ on steel and Jojoba oil ${ }^{10}$ on aluminium. It has also been found that compounds which containing polar elements like nitrogen, sulphur and oxygen which have lone pairs of electrons exhibit good corrosion inhibiting property ${ }^{11}$. The oil of Sesmum indicum is rich in manganese, copper and also contains vitamin $\mathrm{B}_{1}$ (thiamine) and vitamin E (tocopherol). They contains lignans such as sesamol, sesamin and sesamolin. The percentage composition of fatty acid is $44 \%$, stearic acid $4.2 \%$, palmitic acid $9 \%$ and arachidic acid $0.7 \%{ }^{12}$. The presence of sesamol, sesamin 
and sesamoline in Sesmum indicum oil worked as inhibitor in $0.5 \mathrm{~N}$ hydrochloric acid. Thermodynamic, kinetic, electrochemical and adsorption parameters for copper metal in hydrochloric acid with and without of the inhibitor were obtained and interpreted. In view of the above, it was spurred us to study the consequence of Sesmum indicum oil on copper metal's corrosion in $0.5 \mathrm{~N} \mathrm{HCl}$ solution by using gravimetric method and galvanostatic polarization method.

\section{EXPERIMENTAL}

\section{Gravimetric method Materials}

Copper specimens having the composition $0.02030 \% \mathrm{~Pb}, 0.0297 \% \mathrm{Fe}, 0.0103 \% \mathrm{Ni}, 0.0064 \%$ Si , $0.0087 \%$ As, $0.0039 \%$ Co, $0.0015 \%$ Al, $0.0190 \%$ $\mathrm{S}$ and balance part $\mathrm{Cu}$ have been used for the experimental method.

\section{Solutions}

In the experimental, hydrochloric acid was made by analytical reagent grade chemical. Suitable strength $(0.5 \mathrm{~N})$ of hydrochloric acid was made by de-ionized water in with and without of different concentrations of Sesmum indicum oil. The employed concentration range of sesmum indicum was of $1.0 \mathrm{~g}$ to $6.0 \mathrm{~g}$ in $1000 \mathrm{ml}$ of $0.5 \mathrm{~N}$ hydrochloric acid.

\section{Corrosion rates measurements}

Gravimetric method was used to calculate the corrosion parameters. In each weight loss experiment, the test coupon's size $3 \times 2 \times 0.2 \mathrm{~cm}$ was abraded with a different emery paper of different grades. After this, the coupons were cleaned many times with de-ionized water, after dried, coupon stored in a desiccator. Weigh the test coupon exactly, all the coupons were suspended with the help of glass hooks in $50 \mathrm{ml}$ beakers which have $50 \mathrm{ml}$ of 0.5 $\mathrm{N}$ hydrochloric acid in without and with of a certain amount of sesmum indicum. When experimental time 360 minutes was completed, the coupons were taken out, cleaned with de-ionized water, dried in oven and reweighed exactly. The difference between the weight of coupon after immersion time and initial weight of the coupons was considered the mass loss by this we can calculate the rate of corrosion given by ${ }^{12}$ :

Rate of Corrosion (mill miles per year) $=(87.6 \mathrm{~W}) /(\mathrm{dAt})$

In above equation, $\mathrm{W}$ represents mass loss in milligrams, $d$ represents density of the metal $\left(\mathrm{gcm}^{-3}\right)$, A represents surface area of the coupon in square inch and $t$ represents the time of experiment in hours.

The IE (\%) of Sesmum indicum acting as inhibitor in $0.5 \mathrm{~N} \mathrm{HCl}$ acid was obtained by the following formula:

$$
\operatorname{IE}(\%)=\left(1-\mathrm{W}_{\mathrm{i}} / \mathrm{W}_{0}\right) \times 100
$$

At the room temperature, $\mathrm{W}_{\mathrm{o}}$ and $\mathrm{W}_{\mathrm{i}}$ are the mass loss of the copper metal without and with

Table 1: Inhibitor efficiency, rate of corrosion and surface cover by inhibitor at room temperature evaluated by weight loss method for copper metal in $0.5 \mathrm{~N}$ hydrochloric acid (Experimental time: $6 \mathrm{~h}$ )

\begin{tabular}{lcccc}
\hline $\begin{array}{l}\text { Amount of } \\
\text { Inhibitor } \\
\text { (grams/lit) }\end{array}$ & $\begin{array}{c}\text { Weight } \\
\text { Loss } \\
\text { (grams) }\end{array}$ & $\begin{array}{c}\text { Percentage } \\
\text { Inhibitor } \\
\text { Efficiency }\end{array}$ & $\begin{array}{c}\text { Rate of Corrosion } \\
\text { (mill miles per year) }\end{array}$ & $\begin{array}{c}\text { Surface Cover } \\
\text { by Inhibitor( } \theta \text { ) }\end{array}$ \\
\hline 0.0 & 0.0140 & - & 1.62 & \\
1.0 & 0.0042 & 70.00 & 0.48 & 0.7000 \\
2.0 & 0.0038 & 72.85 & 0.44 & 0.7285 \\
3.0 & 0.0035 & 75.00 & 0.40 & 0.7500 \\
4.0 & 0.0032 & 77.14 & 0.37 & 0.7714 \\
5.0 & 0.0030 & 78.57 & 0.34 & 0.7857 \\
6.0 & 0.0028 & 80.00 & 0.32 & 0.8000 \\
\hline
\end{tabular}


inhibitors amount in $\mathrm{HCl}$ acid. The degree of surface coverage $(\theta)$ was evaluated from formula (3)

$$
\theta=1-\left(\mathrm{W}_{\mathrm{i}} / \mathrm{W}_{0}\right)
$$

\section{Electrochemical polarization method}

For electrochemical polarization studies, at room temperature copper strips of similar metal coated with araldite with only open area of $1.0 \mathrm{~cm}^{2}$ was used. The electrochemical measurements were performed in a three-electrode cell. In this cell working electrode was made by copper metal which have $1 \mathrm{~cm}^{2}$ open surface. Reference electrode was made by saturated calomel electrode (SCE) and auxiliary electrode was made by platinum foil.

\section{RESULTS AND DISCUSSION}

\section{Gravimetric measurements}

The loss of weight of copper coupons due to their immersion in solutions of $0.5 \mathrm{~N} \mathrm{HCl}$ containing different concentrations of sesmum indicum was measured. It was found that the addition of sesmum indicum lowers the weight loss of the copper than its value in the free acid solution. The result indicates that the sesmum indicum oil works like effective corrosion inhibitor for copper metal in hydrochloric acid solution. The inhabitation works of sesmum indicum oil could attribute to the molecules adsorption on the copper metal's surface. Hydrocarbon chains were oriented towards aqueous solution. These hydrocarbon chains being hydrophobic in nature repel the corrosion anions away from the metal surface thus create a hindrance between the copper metal and the corrosive territory. The efficiencies of inhibitor (IE \%) with different concentrations of the Sesmum indicum oil are given in (Table 1) and shown in figure 1.

Kinetics parameters of copper metal corrosion in hydrochloric acid absence and presence of Sesmum indicum oil

Figure 2, the graph between $\log W_{f}$ versus experimental time gave a straight line which representing that inhibition action follows first order kinetics. The data of the specific rate constant are obtained using the kinetics first order rate $\operatorname{law}^{13}$.

$$
\log \left(W_{i}-\Delta W_{t}\right)=-(k / 2.303) t+\log W_{i}
$$

In above formula $\mathrm{W}_{\mathrm{i}}$ is the starting weight of the copper metal coupon and $\Delta \mathrm{W}_{\mathrm{t}}$ is the weight loss during experimental time t. The values for halflife $\left(t_{1 / 2}\right)$ were obtained by following formula ${ }^{14}$.

$$
t_{1 / 2}=0.693 / k
$$

The rate constant values and half-life $\left(t_{1 / 2}\right)$ evaluated from the above formula are represented in ( Table 2).

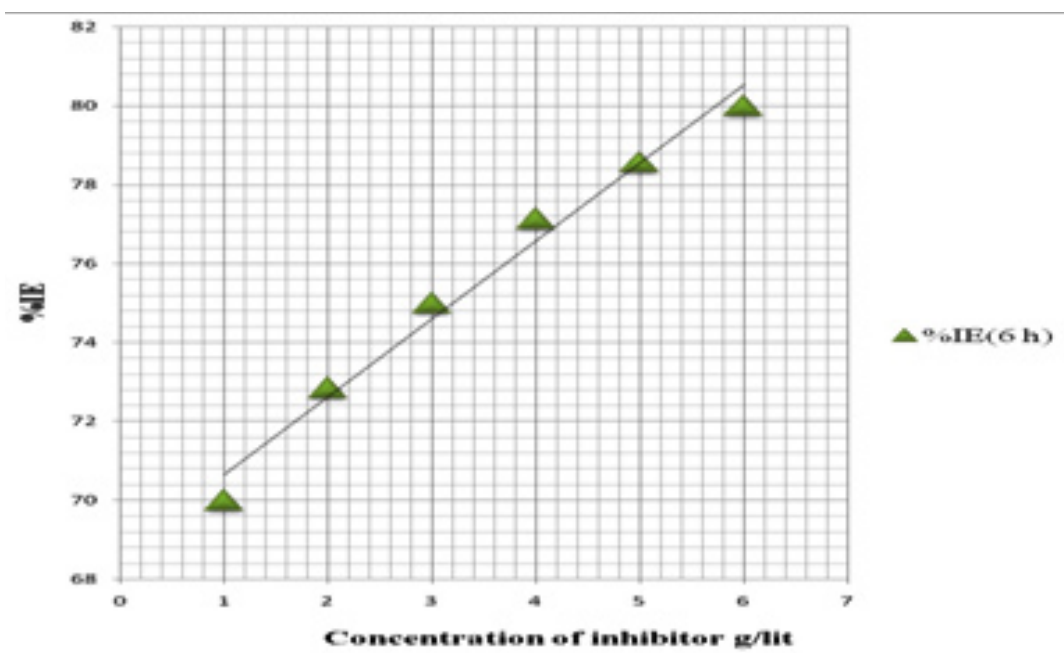

Fig. 1: Effect of Sesmum indicum oil on copper metal in $0.5 \mathrm{~N}$ hydrochloric acid for inhibition efficiency (experimental time: 6 hours) 
The results represented by experiment that when amount of inhibitor increases then values of $k$ (rate constant) decreases and half life increase.

Table 2: Kinetic data of copper with different amount of Sesmum indicum oil

\begin{tabular}{lcc}
\hline $\begin{array}{l}\text { Concentration of } \\
\text { inhibitor(g/lit) }\end{array}$ & $\mathbf{k}\left(\mathbf{s}^{-1}\right)$ & $\mathbf{t}_{1 / 2}(\mathbf{s})$ \\
\hline 0 & $6.9 \times 10^{-8}$ & $1.0 \times 10^{7}$ \\
1 & $1.84 \times 10^{-8}$ & $3.7 \times 10^{7}$ \\
2 & $1.84 \times 10^{-8}$ & $3.7 \times 10^{7}$ \\
3 & $1.84 \times 10^{-8}$ & $3.7 \times 10^{7}$ \\
4 & $1.84 \times 10^{-8}$ & $3.7 \times 10^{7}$ \\
5 & $1.38 \times 10^{-8}$ & $5.0 \times 10^{7}$ \\
6 & $9.2 \times 10^{-9}$ & $7.5 \times 10^{7}$ \\
\hline
\end{tabular}

Thermodynamic and adsorption consideration

Experimental values evaluated for surface coverage $(\theta)$ were applied for many isotherm equations related to adsorption like Langmuir, El-Awady, Frumkin, Freundlich and Florry - Huggins. The final results represent that the isotherms that best described the adsorption feature of sesmum indicum oil on copper metal are Langmuir adsorption isotherms. Degree of surface coverage $(\theta)$ and the

Table 3: Variable of Langmuir adsorption isotherms for the copper metal with sesmum indicum oil

\begin{tabular}{lcccc}
\hline Temperature (k) & $\mathbf{K}_{\text {ad }}$ & Slope & $-\Delta \mathbf{G}_{\text {ads }}$ & $\mathbf{R}^{2}$ \\
\hline 298 & 3.45 & 1.2 & 29.16 & 0.999 \\
\hline
\end{tabular}

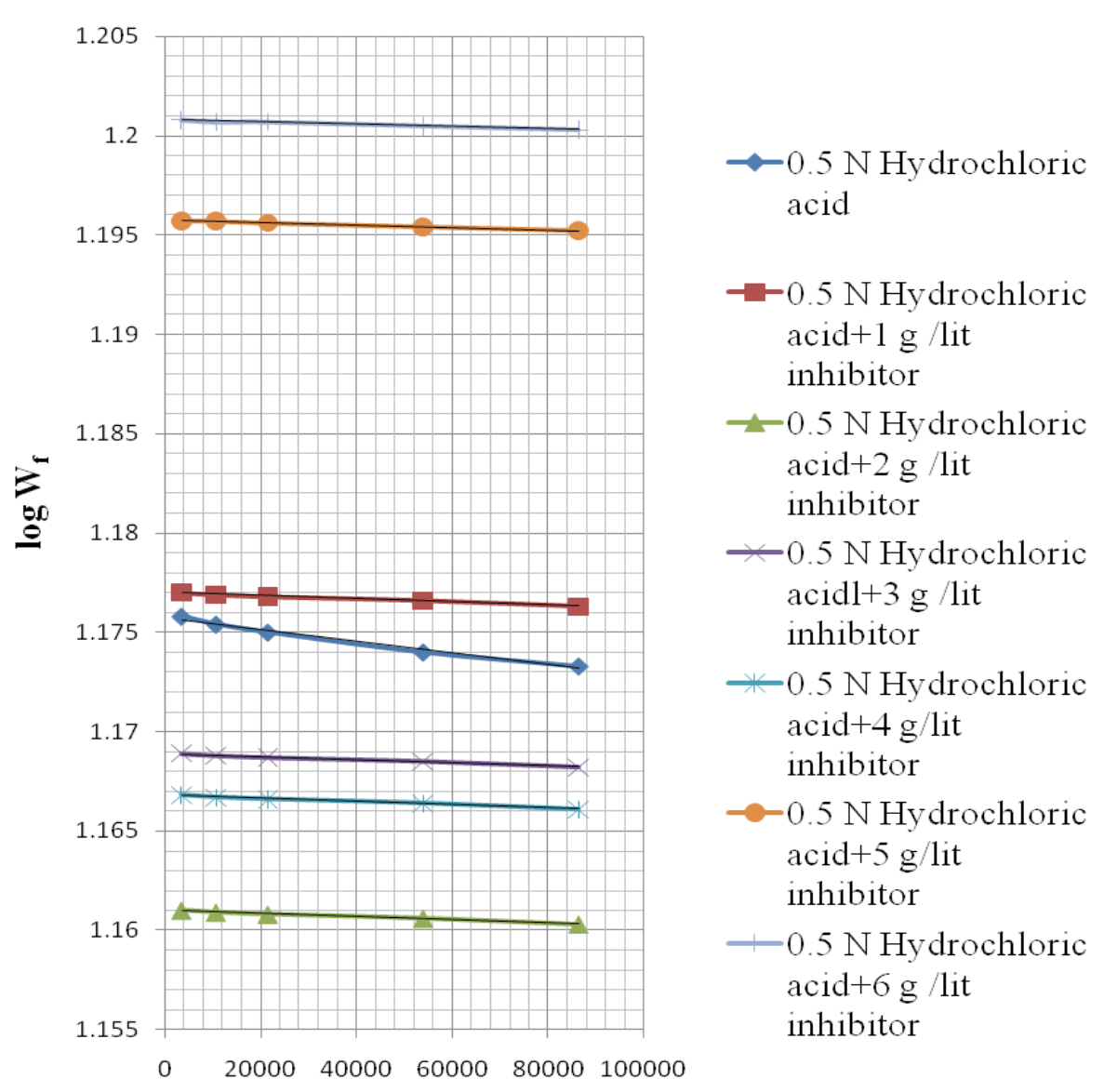

Time in sec.

Fig. 2: Kinetics graph of copper in $0.5 \mathrm{~N}$ hydrochloric acid with absent and presence of inhibitor 
Table 4: Electrochemical polarization values for copper with absence and presence of Sesmum indicum oil in $0.5 \mathrm{~N}$ hydrochloric acid

\begin{tabular}{|c|c|c|c|c|c|}
\hline \multirow{2}{*}{$\begin{array}{l}\text { Concentration of } \\
\text { Inhibitor } \\
\text { (grams /lit) }\end{array}$} & \multirow[b]{2}{*}{$-E_{\text {corr }}(V)$} & \multicolumn{3}{|c|}{ Tafel slopes (V.dec $\left.{ }^{-1}\right)$} & \multirow[b]{2}{*}{ IE\% } \\
\hline & & $\mathbf{b}_{\mathrm{c}}$ & $b_{a}$ & $\mathrm{I}_{\text {corr }}\left(\mathrm{A} \cdot \mathrm{cm}^{-2}\right)$ & \\
\hline 0.0 & 0.365 & 2.009 & 7.158 & $1.289 \times 10^{-5}$ & - \\
\hline 1.0 & 0.387 & 3.908 & 9.388 & $5.950 \times 10^{-6}$ & 53.84 \\
\hline 3.0 & 0.399 & 5.150 & 9.081 & $3.25 \times 10^{-6}$ & 74.78 \\
\hline 5.0 & 0.435 & 6.616 & 9.113 & $1.714 \times 10^{-6}$ & 86.70 \\
\hline
\end{tabular}

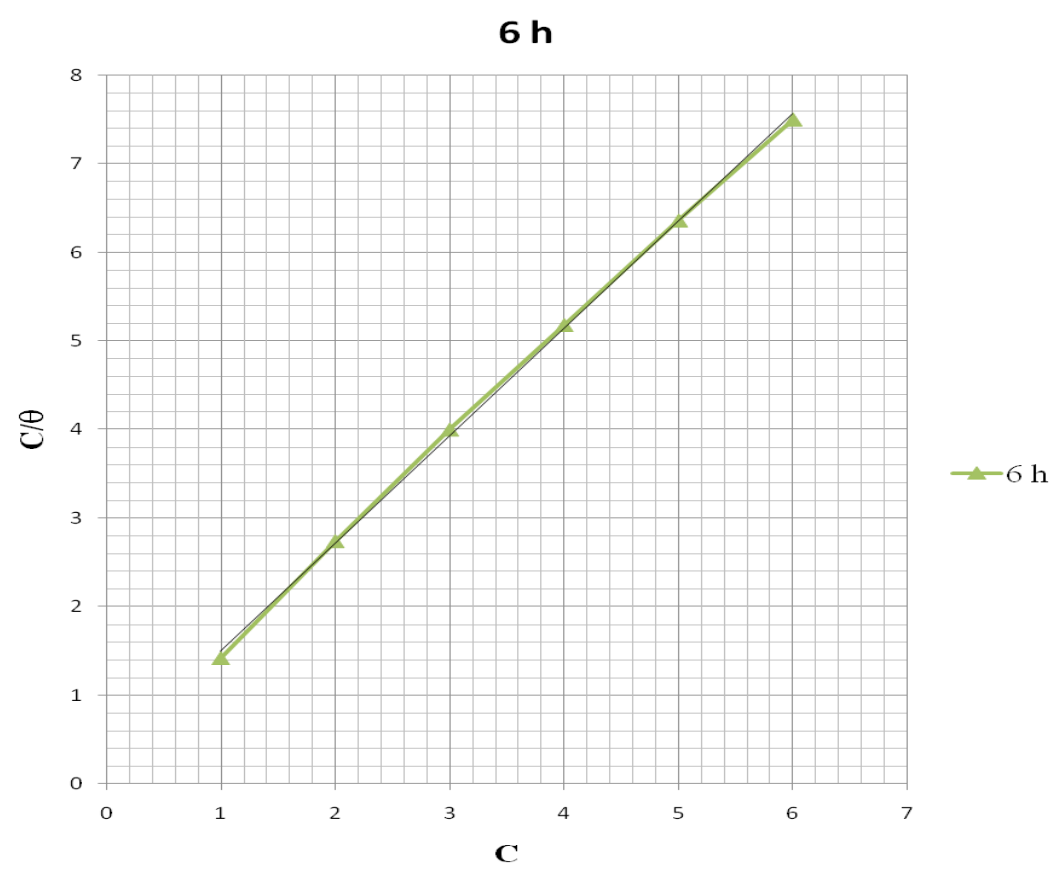

Fig. 3: Langmuir adsorption isotherm of the inhibitor sesmum indicum oil (Experimental time $-6 \mathrm{~h}$ )

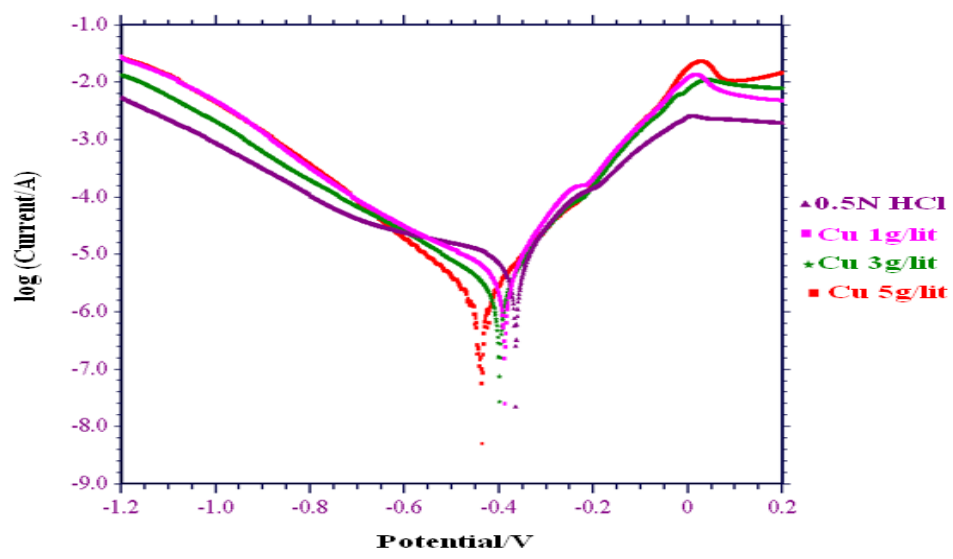

Fig. 4: Cathodic and anodic polarization curve of copper with absence and presence of Sesmum indicum oil in $0.5 \mathrm{~N}$ hydrochloric acid 
amount of the inhibitor in hydrochloric acid are related to following formula (6) according to Langmuir adsorption isotherm.

$$
\mathrm{C} / \theta=1 / \mathrm{K}_{\mathrm{ad}}+\mathrm{C}
$$

Where $\mathrm{C}$ is the amount of Sesmum indicum oil in hydrochloric acid, $\mathrm{K}_{\mathrm{ad}}$ is the equilibrium invariable for Sesmum indicum oil on copper surface.

A graph between $\mathrm{C}$ and $\mathrm{C} / \mathrm{\theta}$ in figure 3 produces a straight line by equation 6 .

\section{Galvanostatic polarization measurements}

Galvanostatic polarization parameters were evaluated for copper metal with and without of inhibitors. Figure 4 shows the galvanostatic polarization plot for sesmum indicum in $0.5 \mathrm{~N} \mathrm{HCl}$ for copper metal with and without of inhibitors at optimized concentration. Galvanostatic polarization values like $\mathrm{E}_{\text {corr }}(\mathrm{V}) \mathrm{I}_{\text {corr }}\left(\mathrm{A} . \mathrm{cm}^{-2}\right)$ and percentage inhibition efficiency are given in table no. 4. Figure 4 shows that both the anodic and cathodic parts of galvanostatic polarization plot are polarized. Sesmum indicum oil adsorbed on the copper metal and hindrance the active sites and thus retards corrosion. ${ }^{16}$

The IE\% was evaluated by using formula:

$$
\mathrm{IE} \%=1-\left(\mathrm{I}_{\text {corr }} / \mathrm{I}_{\text {corr }}\right) \times 100
$$

In above formula $\mathrm{I}_{\text {corr }}$ and $\mathrm{I}_{\text {corr }}$ are corrosion current densities with and without of Sesmum indicum oil in $0.5 \mathrm{~N}$ hydrochloric acid. $\mathrm{E}_{\text {corr }}$ values do not show any signification change suggesting sesmum indicum oil is mixed type inhibitor. The IE\% evaluated from galvanostatic polarization measurements were nicely match with the gravimetric method with little changes.

\section{CONCLUSIONS}

Sesmum indicum oil was found to be the potential corrosion inhibitor. The efficiency of inhibitor was found $86 \%$ in $0.5 \mathrm{~N}$ hydrochloric acid with minor amount of sesmum indicum oil by galvanostatic method. The inhibition efficiency values obtained from gravimetric method and galvanostatic polarization measurements are found to be in close agreement. Kinetics analysis of experimental data confirmed a first order reaction. The negative value of $\left(\Delta \mathrm{G}_{\mathrm{ads}}\right)$ suggests that Sesmum indicum oil is effective adsorbed on copper metal and the process is spontaneous. Oil was adsorbed on the copper surface according to the Langmuir isotherms. The values of $\mathrm{E}_{\text {corr }}$ (by the galvanostatic polarization) are almost constant which shows that the nature of Sesmum indicum oil is mixed type in $0.5 \mathrm{~N}$ hydrochloric acid and blocking both anodic and cathodic reaction to equal extent.

\section{ACKNOWLEDGEMENTS}

Authors are highly thankful to Head, Department of Chemistry, University of Rajasthan, Jaipur and Director (Academic), Swami Keshvanand Institute of Technology, Management \& Gramothan, Jaipur for providing necessary facilities.

\section{REFERENCES}

1. Nnanna, Lebe, Nnanna, George, Nnakaife, Justus, Ekekwe, Nneka, Eti, Peter, Int. J. of Mat. and Chem., 2016, 6(1), 12-18.

2. Al-Fakih, A.M., Aziz1, M., Sirat, H.M., J. Mater. Envcopper. Sci. 2015, 6 (5), 14801487.

3. Okafor, P.C., Ikpi, M.I., Uwah, I.E., Ebenso, E.E., Ekpe, U.J., Umoren, S.A., Corros. Sci., 2008, 50, 2310.

4. Patel,N. S., Jauhariand, S., Mehta, G. N., AlDeyab, S. S., Warad, I., Hammouti, B., Int. J. Electrochem. Sci., , 2013, 8, 2635 - 2655.
5. Odoemelam, S.A., Eddy, N.O., J. Surf. Sci. Technol., 2008, 24, 1.

6. Arockia Selvi, J., Rajendran Susai, Ganga Sri, V., Amalraj, A. John, Narayanasamy, B., Port. Electrochimica Acta, 2009, 27(1), 1-11.

7. Mahmoud, Magda Abdo, Mohamed, Amany , Turk J Chem, 2015, 39, 1078 - 1088.

8. Fouda, A.S., El-khateeb, A. Y., Fakih, M. , Indian J. Sci. Res. 2013, 4(2), 219-227.

9. Bouyanzer, A. , Hammouthi, B., Pigment \& Resin Tech., 2005, 34(6), 327. 
10. Chetouani, A., Hammouthi,B., Benkaddour, M., Pigment \& Resin Tech., 2004, 33(1), 26.

11. Khaled, K.F., Abdel-Shafi, N. S., Al-Mobarak, N. A., Int. J. Electrochem. Sci., 2012, 7, 1027 $-1044$.

12. Pasupathy, A., Raja, T., Raja, M., Int. J. of Sci. and Res. Pub., 2015,5 (2), 1-3.

13. M.Emran, Khadijah, Al-ahmadi, O.Arwa, Torjoman, Bayan A., Ahmed, Najla M., Sheekh, Sara N., Af. J.of pure \& app.chem., 2015, 9(3),39-49.
14. Atkins, P.W., Chemisorbed and Physisorbed Species, A Textbook of Physical Chemistry University Press, Oxford, 1980.

15. Dasami,P.M., Parameswari, K., Chitra, S. Orient. J. Chem., 2015, 31(1), 185-191.

16. Khaled, K.F., Abdelshafi, N. S., El-Maghraby, A. A., Aouniti, A., Al-Mobarak, N., Hammouti, B. Int. J. Electrochem. Sci., 2012, 7, 12706 -12719 . 